\title{
Developing a 7.5-sec site-condition map for Japan based on geomorphologic classification
}

\author{
K. Wakamatsu ${ }^{1} \&$ M. Matsuoka ${ }^{2}$ \\ ${ }^{I}$ Department of Civil and Environmental Engineering, \\ Kanto Gakuin University, Japan \\ ${ }^{2}$ Geoinformation Center, Geological Survey of Japan, \\ National Institute of Advanced Industrial Science and Technology, Japan
}

\begin{abstract}
In a seismic hazard assessment, local geologic and ground conditions play important roles in characterizing and estimating hazards. The authors created a systematically standardized GIS-based ground-condition map containing the attributes of geomorphologic classification in grid cells of 7.5 arc-seconds latitude $\times 11.25$ arc-seconds longitude for all of Japan. This paper introduces the concept of developing the 7.5-arc-second JEGM, and presents sample images of the JEGM. As an example of the database's application to estimating the hazards - the average shear velocity of the ground in the upper $30 \mathrm{~m}-\mathrm{Vs} 30$ is estimated and mapped for all of Japan. As the other examples of the database's application being released by public agencies, presents prefectural seismic risk analyses, Seismic Hazard Maps for Japan, Quick Estimation System for Earthquake Maps triggered by observation records (QuiQuake) are presented.

Keywords: GIS database, geomorphologic land classification, seismic hazard mapping, Vs30, seismic risk analyses.
\end{abstract}

\section{Introduction}

A number of ocean-trench earthquakes including the Tokai, Tonankai and Nankai earthquakes and inland earthquakes hit the Tokyo metropolitan area are expected to occur with high probabilities in the near future in Japan. Local ground conditions play important roles in characterizing and assessing their hazards. However, neither a digital database nor paper maps of ground conditions throughout Japan had been available in a unified form. 
Therefore, the authors have created a systematically standardized GIS-based ground-condition map covering all of Japan, the "Japan Engineering Geomorphologic Classification Map (JEGM)" and released on CD-ROM (Wakamatsu et al. [1]). The database covers all of Japan with a Japanese standard size grid, which is 30 arc-seconds latitude $\mathrm{x} 45$ arc-seconds longitude (approximately $1 \times 1 \mathrm{~km}^{2}$ ) and includes five sets of major attributesgeomorphologic classification, geologic age, slope angle, elevation, and relative relief -in approximately 380,000 grid cells. Among its attributes, the geomorphologic classification database was based on a new engineering-based geomorphologic classification scheme for identifying and classifying subsurface ground conditions.

The JEGM was employed for the following types of nationwide hazard mapping: liquefaction potential (Wakamatsu et al. [1]), average shear velocity of ground in the upper $30 \mathrm{~m}$, Vs30, for estimating the site amplification factors (Matsuoka et al. [2]), flood potential (Wakamatsu et al. [1]), and erosion rate potential in mountainous area (Hasegawa et al. [3]).

To perform more accurate hazard zoning, we had been developed a 7.5-arcsecond Japan Engineering Geomorphologic Classification Map (7.5-arc-second JEGM) for all of Japan, which is a high spatial-resolution version of the abovementioned 30-arc-second JEGM. In this paper, we present the concept behind the development of the 7.5-arc-second engineering geomorphologic classification database (the 7.5-arc-second JEGM) and its application for seismic hazard estimation.

\section{7.5-arc-second JEGM}

\subsection{Concept of mapping}

The map contains an attribute of geomorphologic land classification in grid cells that are 7.5 arc-seconds latitude $\times 11.25$ arc-seconds longitude (approximately $250 \times 250 \mathrm{~m}^{2}$ ) in size. The criteria for 30 arc-second JEGM were used to develop the 7.5-arc-second JEGM, with some additional classifications such as "lowland between coastal dunes and/or bars," "rock shore, rock reef," "dry river bed," which are negligible areas in the 1-km square grid cell. A description of geomorphologic map units is presented in Table 1, together with the corresponding general ground conditions and general depth of groundwater. These criteria were based on the purpose of the mapping project: identification and classification of subsurface ground conditions, through standard geomorphologic classification. The geomorphologic factors presented in table 1 are known to be correlated with subsurface ground and hydrologic conditions (e.g. Zuidam et al. [4]). 
Table 1: Description of geomorphologic map units in the 7.5-arc-second JEGM.

\begin{tabular}{|c|c|c|c|}
\hline $\begin{array}{l}\text { Geomorpholo } \\
\text { gic map unit }\end{array}$ & Definition and general characteristics & Subsurface soil condition & $\begin{array}{l}\text { General depth of } \\
\text { groundwater* }\end{array}$ \\
\hline Mountain & $\begin{array}{c}\text { Steeply to very steeply sloping } \\
\text { topography with highest elevation and } \\
\text { relative relief within a grid cell of more } \\
\text { than approximately } 200 \mathrm{~m} \text {. Moderately } \\
\text { to severely dissected. }\end{array}$ & $\begin{array}{l}\text { Pre-Quaternary hard to } \\
\text { soft rock. }\end{array}$ & Deep \\
\hline $\begin{array}{l}\text { Mountain } \\
\text { footslope }\end{array}$ & $\begin{array}{l}\text { Gently sloping topography adjoining } \\
\text { mountains and composed of material } \\
\text { sourced from the mountains such as } \\
\text { colluvium, talus, landslide, and debris } \\
\text { flow deposits. }\end{array}$ & $\begin{array}{l}\text { Loose debris and soils } \\
\text { consisting of colluvium, } \\
\text { talus, landslide, and } \\
\text { debris flow deposits. }\end{array}$ & Deep \\
\hline Hill & $\begin{array}{l}\text { Steeply to moderately sloping } \\
\text { topography with higher elevation and } \\
\text { relative relief within a grid cell of } \\
\text { approximately } 200 \mathrm{~m} \text { or less. } \\
\text { Moderately dissected. }\end{array}$ & $\begin{array}{l}\text { Pre- Quaternary and } \\
\text { Quaternary hard to soft } \\
\text { rock. }\end{array}$ & Deep \\
\hline Volcano & $\begin{array}{c}\text { Steeply to moderately sloping } \\
\text { topography with higher elevation and } \\
\text { larger relative relief, composed of } \\
\text { Quaternary volcanic rocks and } \\
\text { deposits. }\end{array}$ & $\begin{array}{l}\text { Quaternary hard to soft } \\
\text { volcanic rock and/or } \\
\text { deposits. }\end{array}$ & Deep \\
\hline $\begin{array}{l}\text { Volcanic } \\
\text { footslope }\end{array}$ & $\begin{array}{l}\text { Gently sloping topography located } \\
\text { around skirt of volcano including } \\
\text { pyroclastic-, mud- and lava-flow fields, } \\
\text { and volcanic fan produced by } \\
\text { dissection of volcanic body. Slightly } \\
\text { dissected. }\end{array}$ & $\begin{array}{c}\text { Quaternary loose to } \\
\text { dense volcanic deposits } \\
\text { consisting of ash, scoria, } \\
\text { pumice, pyroclastic flow, } \\
\text { lava, debris avalanche, } \\
\text { etc. }\end{array}$ & Deep \\
\hline Volcanic hill & $\begin{array}{l}\text { Moderately sloping topography } \\
\text { composed of pyroclastic flow deposits. } \\
\text { Moderately to severely dissected. }\end{array}$ & $\begin{array}{l}\text { Loose to moderately } \\
\text { loose pyroclastic flow } \\
\text { deposits such as ash, } \\
\text { scoria, and pumice. }\end{array}$ & Deep \\
\hline $\begin{array}{l}\text { Rocky strath } \\
\text { terrace }\end{array}$ & $\begin{array}{c}\text { Fluvial or marine terrace with flat } \\
\text { surface and step-like form, including } \\
\text { limestone terrace of emerged coral reef. } \\
\text { Thickness of subsurface soil deposits is } \\
\text { less than } 5 \mathrm{~m} \text {. }\end{array}$ & Hard to soft rock. & Deep \\
\hline $\begin{array}{l}\text { Gravelly } \\
\text { terrace }\end{array}$ & $\begin{array}{l}\text { Fluvial or marine terrace with flat } \\
\text { surface and step-like form. Covered } \\
\text { with subsurface deposits (gravel or } \\
\text { sandy soils) more than } 5 \mathrm{~m} \text { thick. }\end{array}$ & Dense gravelly soil. & Deep \\
\hline $\begin{array}{c}\text { Terrace } \\
\text { covered with } \\
\text { volcanic ash } \\
\text { soil }\end{array}$ & $\begin{array}{c}\text { Fluvial or marine terrace with flat } \\
\text { surface and step-like form. Covered } \\
\text { with cohesive volcanic ash soil to more } \\
\text { than } 5 \mathrm{~m} \text { thick. }\end{array}$ & $\begin{array}{l}\text { Stiff volcanic ash } \\
\text { (cohesive soil). }\end{array}$ & Deep \\
\hline $\begin{array}{c}\text { Valley bottom } \\
\text { lowland }\end{array}$ & $\begin{array}{l}\text { Long and narrow lowland formed by } \\
\text { river or stream between steep to } \\
\text { extremely steep slopes of mountain, } \\
\text { hill, volcano, and terrace. }\end{array}$ & $\begin{array}{l}\text { Moderately dense to } \\
\text { dense gravel or boulders } \\
\text { in mountain, but loose } \\
\text { sandy soil to very soft } \\
\text { cohesive soil in plain. }\end{array}$ & Shallow \\
\hline Alluvial fan & $\begin{array}{c}\text { Semi-cone-like form composed of } \\
\text { coarse materials, which is formed at the } \\
\text { boundary between mountains and } \\
\text { lowland. Slope gradient is more than } \\
1 / 1000 \text {. }\end{array}$ & $\begin{array}{l}\text { Dense gravel with } \\
\text { boulders to moderately } \\
\text { dense sandy gravel. }\end{array}$ & $\begin{array}{c}\text { Deep in the } \\
\text { central part of } \\
\text { fan but shallow } \\
\text { in the distal part } \\
\text { of fan }\end{array}$ \\
\hline
\end{tabular}




\subsection{Procedure of mapping}

First, the preliminary map was compiled; the major geomorphologic units were evaluated and classified on the basis of the 30-arc-second JEGM and interpretation of topographic maps. The detailed geomorphologic surveys of local geomorphologic features at scales of 1: 50,000 were subsequently performed to delineate units on the basis of the criteria listed in table 1, based on interpretation and compilation of existing information, which is available from published reports, papers, topographical maps, and other available maps and boring exploration data, in addition to our expertise in geomorphology and geotechnical engineering. Finally, a detailed map was drawn up, and digitized and stored in cells using GIS software. Each cell is assigned to the single geomorphologic unit that occupies the greatest area of the cell when multiple units exist within the cell.

Figure 1 shows a sample image of the 7.5-arc-second JEGM for all of Japan. The total number of cells of the map is approximately 6 million.

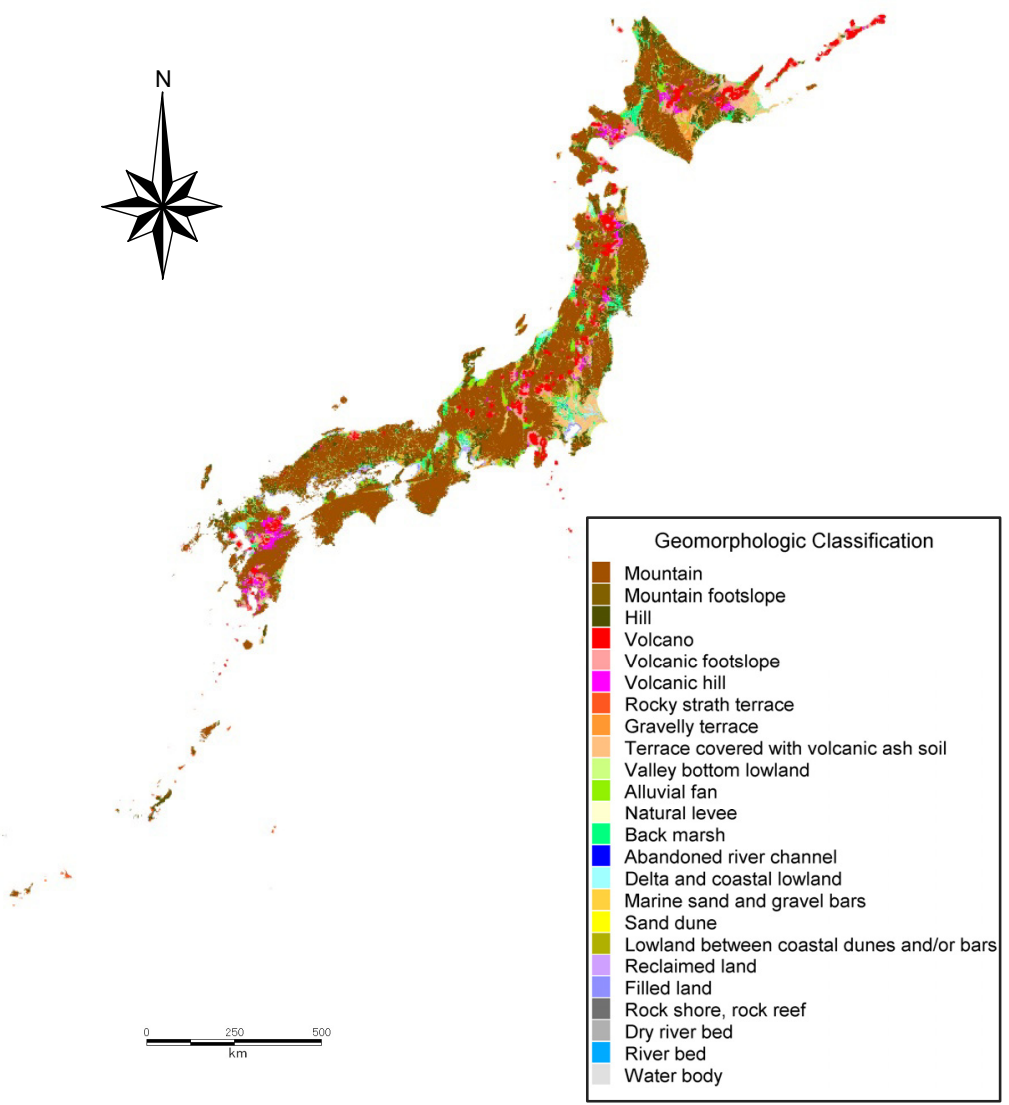

Figure 1: $\quad 7.5$ arc-second JEGM for all of Japan. 


\section{Average shear-wave velocity (Vs30) mapping using the 7.5-arc-second JEGM}

Shear-wave velocity in the upper 30 meters, Vs30 is observed or estimated using borehole data and it is important parameter for evaluating the seismic micro zoning with consideration of site effect during ground motion (Borcherdt [5]).

In a previous study (Matsuoka et al. [2]), we calculated the Vs30, covering approximately 2,000 sites all over Japan where shear-wave velocity has been measured. Geomorphologic units for all PS logging data sites were interpreted using the original data of the 30-second JEGM. Next, we examined the correlation between not only geomorphologic units but also geographical information derived from the JEGM and the Vs30 values. We found that the Vs30s showed some dependency on altitudes, slopes, and distances from mountains or hills formed during older periods (Pre-Tertiary or Tertiary). Multiple linear regression formulae for each geomorphologic unit was developed to estimate the Vs30 using elevation $(E v)$, slope $(S p)$, and distance $(D m)$ from a mountain or a hill as explanatory variables. The basic regression formula is the following equation:

$$
\log \mathrm{Vs} 30=a+b \log E v+c \log S p+d \log D m \pm \sigma
$$

where $a, b, c$, and $d$ represent regression coefficients, and $\sigma$ is the standard deviation. The units of $E v, S p$, and $D m$ are meters, 1000 times tangent values, and kilometers, respectively. When the value of the explanatory variable is less than 1 , we fixed the value as " 1 ".

Table 2 shows the regression coefficients and standard deviation of each geomorphologic unit obtained by regression analysis. The regression coefficients show that the higher the elevation, the steeper the slope, and the shorter the distance from the mountain or the hill, Vs30 values become larger. As for the logarithmic standard deviation for the overall estimation, the estimation formula shown in Equation 1 has a higher accuracy than previous empirical estimations.

Using Equation 1 and the attributes of the geomorphologic classification in the 7.5-arc-second JEGM, geologic age, elevation, and slope contained in the 30arc-second JEGM, we were able to compute the Vs30 distribution with $250 \mathrm{~m}$ spatial resolution. Figure 2 shows the Vs30 map for all of Japan. The Vs30 values are approximately $150 \mathrm{~m} / \mathrm{s}$ on delta and coastal lowland, reclaimed land, and back marsh. The areas of valley bottom lowland also show a rather small $\mathrm{Vs} 30$ in the range from 180 to $200 \mathrm{~m} / \mathrm{s}$.

To draw an amplification capability map, the Vs30 was converted into the amplification factor for $\mathrm{PGV}$ with respect to stiff soil, which corresponds to ground with Vs30 of $600 \mathrm{~m} / \mathrm{s}$, through an empirical relationship (Fujimoto and Midorikawa [6]). The amplification map for all of Japan is shown in fig. 3. 
Table 2: Description of geomorphologic map units in the 7.5-arc-second JEGM (Cont.).

\begin{tabular}{|c|c|c|c|}
\hline $\begin{array}{l}\text { Geomorpholo } \\
\text { gic map unit }\end{array}$ & Definition and general characteristics & Subsurface soil condition & $\begin{array}{l}\text { General depth of } \\
\text { groundwater* }\end{array}$ \\
\hline Natural levee & \begin{tabular}{|c|}
$\begin{array}{c}\text { Slightly elevated area formed along the } \\
\text { riverbank caused by fluvial deposition } \\
\text { during floods. }\end{array}$ \\
\end{tabular} & Loose sandy soil. & Shallow \\
\hline Back marsh & $\begin{array}{c}\text { Swampy lowland formed behind } \\
\text { natural levees and lowlands surrounded } \\
\text { by mountains, hills, and terraces. }\end{array}$ & $\begin{array}{l}\text { Very soft cohesive soil } \\
\text { containing peat or humus. }\end{array}$ & Very shallow \\
\hline $\begin{array}{c}\text { Abandoned } \\
\text { river channels }\end{array}$ & $\begin{array}{l}\text { Swampy shallow depression along } \\
\text { former river course with elongated } \\
\text { shape. }\end{array}$ & $\begin{array}{c}\text { Very loose sandy soil } \\
\text { occasionally covered with } \\
\text { soft cohesive soil. }\end{array}$ & Very shallow \\
\hline $\begin{array}{l}\text { Delta and } \\
\text { coastal } \\
\text { lowland }\end{array}$ & \begin{tabular}{|c|} 
Delta: flat lowland formed at the river \\
mouth by fluvial accumulation. Coastal \\
lowland: flat lowland formed along \\
shoreline by emergence of shallow \\
submarine deposits, including \\
discontinuous lowlands along sea- or \\
lake- shore. \\
\end{tabular} & $\begin{array}{l}\text { Loose fluvial sandy soil } \\
\text { over-lying very soft } \\
\text { cohesive soil. }\end{array}$ & Shallow \\
\hline $\begin{array}{l}\text { Marine sand } \\
\text { and gravel } \\
\text { bars }\end{array}$ & $\begin{array}{c}\text { Slightly elevated topography formed } \\
\text { along shoreline, composed of sand and } \\
\text { gravel, which was washed ashore by } \\
\text { ocean wave and/or current action. }\end{array}$ & $\begin{array}{l}\text { Moderately dense to } \\
\text { dense marine sand or } \\
\text { gravel occasionally with } \\
\text { boulder. }\end{array}$ & Shallow \\
\hline Sand dune & $\begin{array}{l}\text { Wavy topography usually formed } \\
\text { along shoreline or river, comprised of } \\
\text { fine to moderately aeolian sand; } \\
\text { generally overlies sandy lowland. }\end{array}$ & $\begin{array}{l}\text { Very loose to loose fine to } \\
\text { medium sand. }\end{array}$ & $\begin{array}{c}\text { Deep at crest of } \\
\text { dune but shallow } \\
\text { near base of } \\
\text { dune }\end{array}$ \\
\hline $\begin{array}{l}\text { Lowland } \\
\text { between } \\
\text { coastal dunes } \\
\text { and/or bars }\end{array}$ & $\begin{array}{l}\text { Swampy lowland formed behind dunes } \\
\text { or bars }\end{array}$ & $\begin{array}{l}\text { Very soft cohesive soil } \\
\text { containing peat or humus. }\end{array}$ & Very shallow \\
\hline $\begin{array}{l}\text { Reclaimed } \\
\text { land }\end{array}$ & $\begin{array}{c}\text { Former bottom flat of sea, lake, lagoon, } \\
\text { or river that has been reclaimed as land } \\
\text { by drainage. }\end{array}$ & $\begin{array}{c}\text { Loose sand overlying very } \\
\text { soft cohesive soil, } \\
\text { sometimes covered with } \\
\text { loose sandy fill. }\end{array}$ & Very shallow \\
\hline Filled land & $\begin{array}{c}\text { Former water body such as sea, lake, } \\
\text { lagoon, or river reclaimed as land by } \\
\text { filling. }\end{array}$ & $\begin{array}{c}\text { Very loose to loose sandy } \\
\text { fill, overlying very soft } \\
\text { cohesive soil or loose } \\
\text { sandy soils. }\end{array}$ & $\begin{array}{l}\text { Very shallow to } \\
\text { shallow }\end{array}$ \\
\hline $\begin{array}{l}\text { Rock shore, } \\
\text { Rock reef }\end{array}$ & $\begin{array}{l}\text { Irregular topography of rock or coral } \\
\text { around beach zone. }\end{array}$ & $\begin{array}{l}\text { Pre- Quaternary and } \\
\text { Quaternary hard to soft } \\
\text { rock }\end{array}$ & Near sea level \\
\hline Dry riverbed & $\begin{array}{l}\text { Nearly flat, irregular topography } \\
\text { without water in normal time. }\end{array}$ & $\begin{array}{c}\text { Loose sandy to gravelly } \\
\text { alluvial soil, occasionally } \\
\text { with boulders. }\end{array}$ & Very shallow \\
\hline River bed & \begin{tabular}{|c|} 
Nearly flat, irregular topography with \\
varying water cover and having erosion \\
and accumulation parts.
\end{tabular} & $\begin{array}{c}\text { Loose sandy to gravelly } \\
\text { alluvial soil, occasionally } \\
\text { with boulders }\end{array}$ & \\
\hline Lake & Inland water body. & & \\
\hline $\begin{array}{l}\text { Nearshore } \\
\text { waters }\end{array}$ & Nearshore water body. & & \\
\hline
\end{tabular}

*Deep: deeper than $3 \mathrm{~m}$ below the ground surface, Shallow: within $3 \mathrm{~m}$ of the ground surface, Very shallow: within $1 \mathrm{~m}$ of the ground surface. 


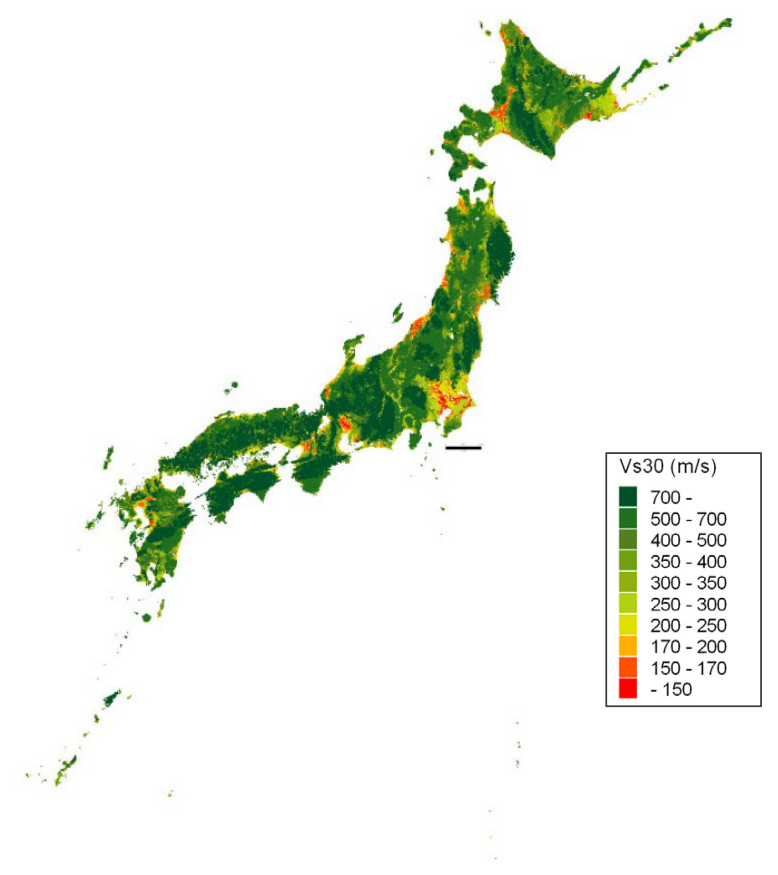

Figure 2: Vs30 map calculated from the 7.5-arc- second JEGM.

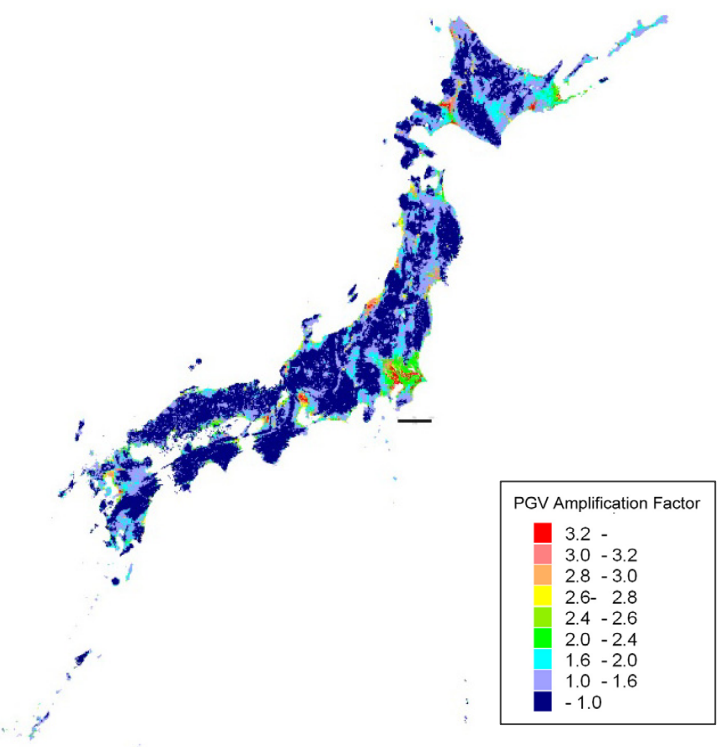

Figure 3: $\quad$ PGV site amplification map converted from Vs30 map. 
Table 3: $\quad$ Regression coefficient (Matsuoka et al. [2]).

\begin{tabular}{|c|cccc|c|}
\hline \multirow{2}{*}{ Geomorphologic map unit } & \multicolumn{4}{|c|}{ Regression coefficient } & s.d. \\
\cline { 2 - 5 } & $a$ & $b$ & $c$ & $d$ & s \\
\hline Mountain (Pre-Tertiary) & 2.900 & 0 & 0 & 0 & 0.139 \\
Mountain (Tertiary) & 2.807 & 0 & 0 & 0 & 0.117 \\
Mountain footslope & 2.602 & 0 & 0 & 0 & 0.092 \\
Hill & 2.349 & 0 & 0.152 & 0 & 0.175 \\
Volcano & 2.708 & 0 & 0 & 0 & 0.162 \\
Volcanic footslope & 2.315 & 0 & 0.094 & 0 & 0.100 \\
Volcanic hill & 2.608 & 0 & 0 & 0 & 0.059 \\
Rocky strath terrace & 2.546 & 0 & 0 & 0 & 0.094 \\
Gravelly terrace & 2.493 & 0.072 & 0.027 & -0.164 & 0.122 \\
Terrace covered with volcanic ash soil & 2.206 & 0.093 & 0.065 & 0 & 0.115 \\
Valley bottom lowland & 2.266 & 0.144 & 0.016 & -0.113 & 0.158 \\
Alluvial fan & 2.350 & 0.085 & 0.015 & 0 & 0.116 \\
Natural levee & 2.204 & 0.100 & 0 & 0 & 0.124 \\
Back marsh & 2.190 & 0.038 & 0 & -0.041 & 0.116 \\
Abandoned river channel & 2.264 & 0 & 0 & 0 & 0.091 \\
Delta and coastal lowland & 2.317 & 0 & 0 & -0.103 & 0.107 \\
Marine sand and gravel bars & 2.415 & 0 & 0 & 0 & 0.114 \\
Sand dune & 2.289 & 0 & 0 & 0 & 0.123 \\
Reclaimed land & 2.373 & 0 & 0 & -0.124 & 0.123 \\
Filled land & 2.404 & 0 & 0 & -0.139 & 0.120 \\
\hline
\end{tabular}

\section{Utilization of 7.5-arc-second JEGM and Vs30 map}

In recent years, the 7.5-arc-second JEGM and the JEGM based Vs30 map have been employed various kinds of seismic hazard mappings in Japan. We introduce several examples of utilization of the both maps.

\subsection{Prefectural seismic risk analyses}

The Basic Law on Natural Disasters [7] obliges concerned government bodies and local governments to work out plans to prepare for disasters based on central government measures. Seismic risk analyses have been carried out to develop regional disaster prevention planning. In these analyses, the 7.5-arc-second JEGM has been used to develop the subsurface ground model for seismic intensity mapping and liquefaction hazard mapping for scenario earthquakes; target area is divided into $250 \mathrm{~m}$ size grid cell and representative soil profile in each cell is evaluated from the borehole data in the cell; it is estimated considering the geomorphologic classification of the 7.5-arc-second JEGM when there is no borehole data in the cell (Saitama Prefecture [8]; Chiba Prefecture [9]; Kanagawa Prefecture [10]). In some cases the JEGM based Vs 30 map is directly used to evaluate the site amplification for seismic intensity (Tokyo metropolitan government [11]). Figure 4 shows seismic intensity map of Tokyo metropolitan for a 7.3-JMA magnitude scenario earthquake centered in northern Tokyo Bay. 


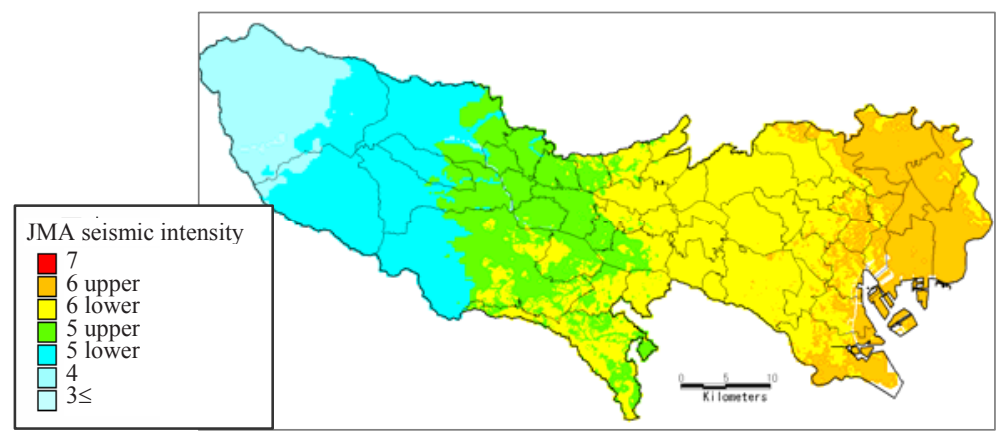

Figure 4: Seismic intensity map of Tokyo metropolitan for 7.3-JMA magnitude scenario earthquake centered in northern Tokyo Bay [11].

\subsection{National Seismic Hazard Maps for Japan}

The Headquarters for Earthquake Research Promotion, Ministry of Education, Culture, Sports, Science and Technology have been prepared and released the National Seismic Hazard Maps for Japan every January 1st shince 2005 [12]. This work is initiated by the earthquake research committee (ERC) on a basis of a long-term evaluation of seismic activity, and evaluation of strong ground motion. The hazard map consists of two kinds of maps; one is a probabilistic seismic hazard map (PSHM) that shows the relation between seismic intensity value and its probability of exceedance within a certain time period. Another one is a scenario earthquake shaking map (SESM). The national seismic hazard maps for the PSHM, an empirical attenuation formula is used following the seismic activity modeling by ERC, and peak ground velocity for sites is evaluated.

The 7.5-arc-second JEGM based Vs 30 map was employed from 2009 version to evaluate site amplification in every 7.5-arc-second grid-cell of the PSHM. The hazard maps and various information to produce the maps, such as data on seismic activities, seismic source models and underground structures are released by Web-GIS at the Japan Seismic Hazard Information Station (J-SHIS) [13]. 2011 version of the PSHM is presented in fig. 5.

\subsection{Quick estimation system for earthquake maps triggered by observation records (QuiQuake)}

The Quick Estimation System for Earthquake Maps Triggered by Observation Records (QuiQuake) is a system which provides wide-ranging and detailed strong motion ground motion maps, based on information such as peak ground velocity and JMA instrumental seismic intensity, soon after an earthquake occurs. The website [14] has been published by the National Institute of Advanced Industrial Science and Technology (AIST) since October 13, 2009. The system uses combinations of the 7.5-arc-second JEGM based amplification capability and observed seismic records. In this system, automatic calculation of spatial interpolation, including consideration of attenuation characteristics from 
the seismic source, is immediately activated by harvesting the seismic data recorded at strong ground motion observation stations (K-NET and KiK-net) operated by the National Research Institute for Earth Science and Disaster Prevention (NIED).

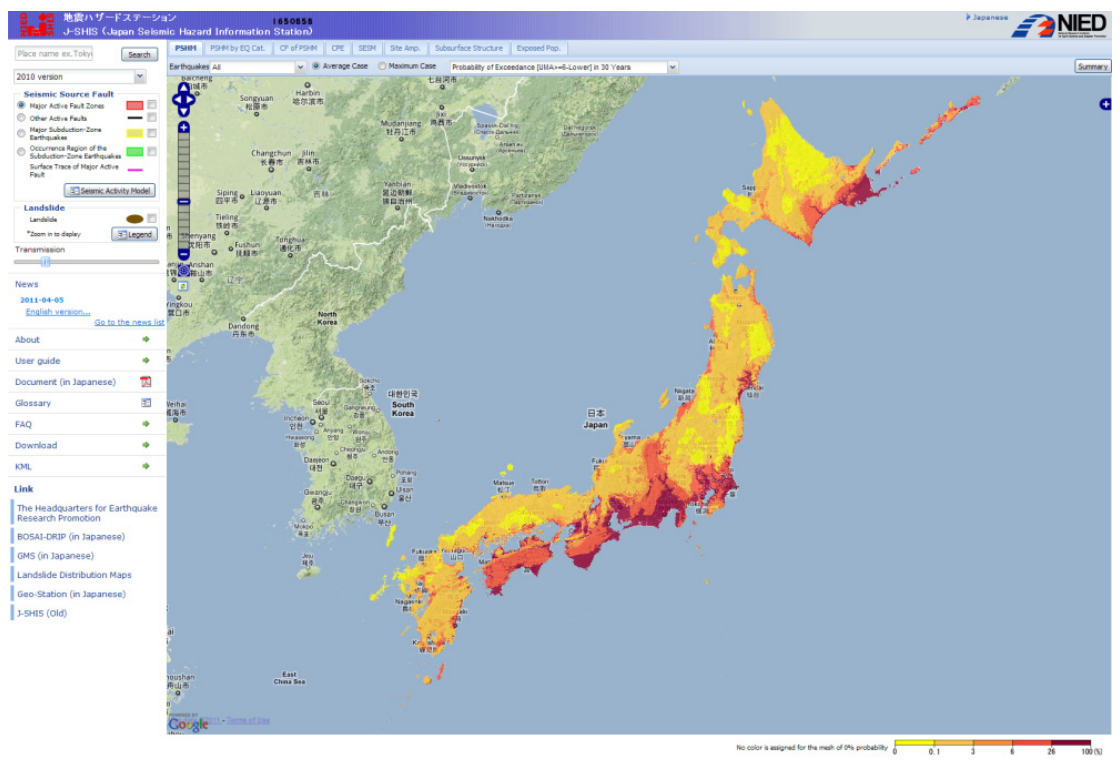

Figure 5: Probability of exceedance of seismic intensity 6 lower of PSHM within 30 years for average case considering all earthquakes.

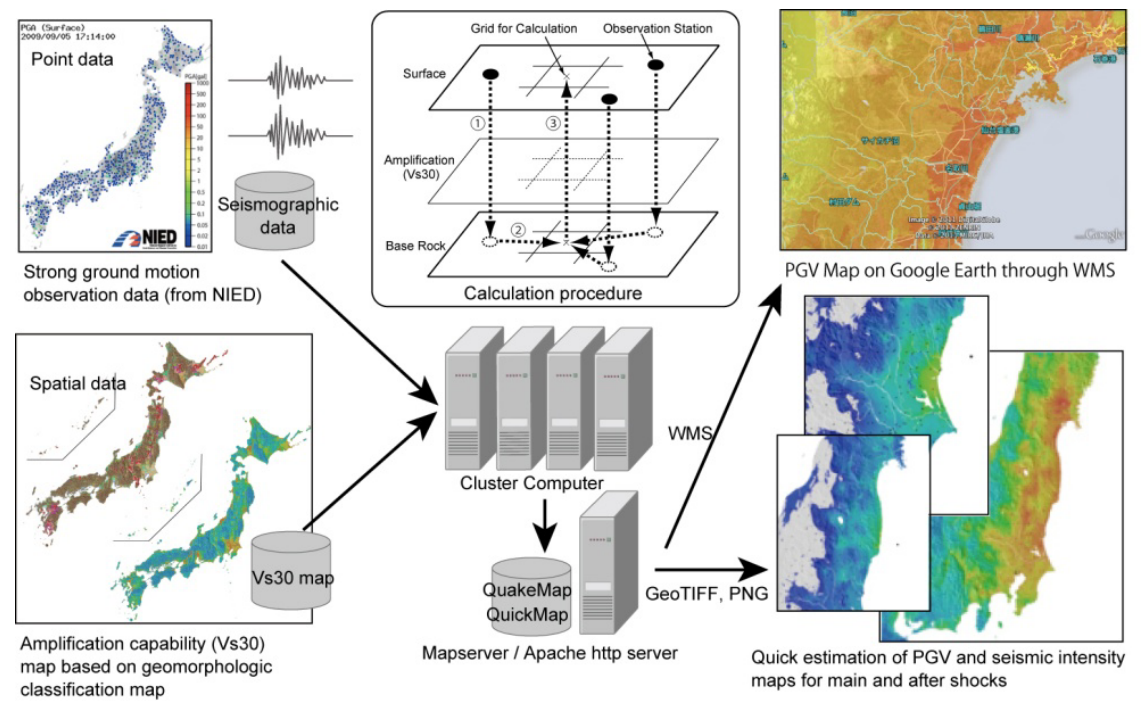

Figure 6: System overview and calculation procedure of QuiQuake. 
Furthermore, ground motion maps for more than 5,000 major earthquakes after June 1996 have been computed and archived such that they chronologically represent the seismic motions over the last 15 years. The strong motion maps are also published through an OGC (Open Geospatial Consortium) standard web service interface. It is expected that these maps will be used as fundamental information for municipalities and private companies to develop business continuity plans (BCPs) and to take effective countermeasures against seismic disasters. The schematic overview of QuiQuake is shown in fig. 6.

\section{Concluding remarks}

In this paper, we introduce the 7.5-arc-second "Japan Engineering Geomorphologic Classification Map (JEGM)," the high spatial-resolution version of 30-arc-second JEGM, which was based on engineering-based geomorphologic classification standards; the concept and procedure of mapping are described, and the image samples of 7.5-arc-second JEGM for major urban areas in Japan are presented. As an example of the database's application to detailed and accurate hazard zoning, we estimated and mapped the average shear-wave velocity of the ground in the upper $30 \mathrm{~m}$, Vs30 for all of Japan and introduce some other utilization for seismic hazard mapping released by public organization. The digital data of the 7.5-arc-second JEGM, Vs30 map and PGV site amplification map converted from Vs30 map are released on line: http://www.j-shis.bosai.go.jp/JSHIS2/download.html?lang=en

\section{Acknowledgements}

The developing the 7.5-arc-second JEGM was done as a part of the project 'Development of Integrated Geophysical and Geological Information Database' sponsored by the Special Coordination Fund for Science and Technology Promotion of Japan. QuiQuake is supported by strong ground motion observation stations operated by National Research Institute for Earth Science and Disaster Prevention (NIED). The authors gratefully acknowledge these supports.

\section{References}

[1] Wakamatsu, K., Kubo, S., Matsuoka, M., Hasegawa, K. \& Sugiura, M., Japan Engineering Geomorphologic Classification Map with CD-ROM Database, University of Tokyo Press, Tokyo, 2005. (in Japanese with English abstract and manual)

[2] Matsuoka, M., Wakamatsu, K., Fujimoto K., \& Midorikawa, S., Average shear-wave velocity mapping using Japan Engineering Geomorphologic Classification Map, Journal of Structural Engineering and Earthquake Engineering, 23-1, 57s-68s, 2006. 
[3] Hasegawa, K., Wakamatsu, K. \& Matsuoka, M., GIS-based Nationwide Evaluation of Erosion Rate Potential in Japan, Proc. 2nd Japan-Taiwan Joint Workshop on Geotechnical Hazards from Large Earthquakes and Heavy Rainfall, ATC3-ISSMGE, pp.108-113, 2006.

[4] Zuidam R. A et al., Aerial Photo-Interpretation in Terrain Analysis and Geomorphologic Mapping, Smits Publishers, Hague, 1986.

[5] Borcherdt, R.D., Effects of local geology on ground motion near sanFrancisco Bay, Bulletion of Seismological Society of America, pp.29$61,1970$.

[6] Fujimoto, K. \& Midorikawa, S., Average shear-wave velocity mapping throughout Japan using the Digital National Land Information, J. Japan Association for Earthquake Engineering, Vol.3, No.3, pp.13-27, 2003. (in Japanese with English abstract)

[7] Ministry of Internal Affairs and Communications, The Basic Law on Natural Disasters, 1961, http://law.e-gov.go.jp/htmldata/S36 /S36HO223.html

[8] Saitama Prefecture, Report on Seismic Damage against Scenario Earthquakes in Saitama Prefecture, http://www.pref.saitama.lg.jp/ page/h19higaisoutei.html (in Japanese), cited in 2007 (in Japanese).

[9] Chiba Prefecture, Report on Seismic Damage against Scenario Earthquakes in Chiba Prefecture, https://www.pref.chiba.lg.jp/bousai/jishin/higaichousa /houkokusho.html (in Japanese) cited in 2008 (in Japanese).

[10] Kanagawa Prefecture, Report on Seismic Damage against Scenario Earthquakes in Kanagawa Prefecture, http://www.pref.kanagawa.jp/osirase/ saigai/chousakekka/soutei21.htm cited in 2009 (in Japanese)

[11] Tokyo metropolitan government, Report on Seismic Damage against Scenario Earthquakes in Tokyo metropolitan, http://www.bousai.metro.tokyo.jp/japanese/tmg/research.html cited in 2006 (in Japanese)

[12] The Headquarters for Earthquake Research Promotion, National Seismic Hazard Maps for Japan, http://www.jishin.go.jp/main/index-e.html

[13] National Research Institute for Earth Science and Disaster Prevention, Japan Seismic Hazard Information Station (J-SHIS), http://www.jshis.bosai.go.jp/?lang=en

[14] National Institute of Advanced Industrial Science and Technology, Quick Estimation System for Earthquake Maps triggered by observation records (QuiQuake), http://qq.ghz.geogrid.org/QuakeMap/index.en.html 